\title{
TIPOLOGI BANGUNAN DI JALAN PAKUBOWONO KEBAYORAN BARU, JAKARTA SELATAN
}

\author{
Yosica Mariana \\ Architecture Department, Faculty of Engineering, Binus University \\ Jl. K.H. Syahdan No. 9, Palmerah, Jakarta Barat 11480 \\ mariana_yosica@binus.ac.id
}

\begin{abstract}
Façade is the front of the building which is facing the street. It is one of the architectural elements of the city that can" speak out" the meaning of the building. In addition, façade is also a part of urban environment order which needs to be sustainable. The transformation of building function often impacts on changes in the composition of façade. Therefore, it is very interesting to be observed, especially along Pakubowono's street, which has distinctively Jengki architectural buildings. The purpose of this study is to explore the the extent of architectural transformation that occurs in Jengki style building by using descriptive methods. The result showed that Pakubowono area has undergone a change and assimilation of forms, although it is not very significant in the building typology. There are many changes that occur in materials and building elements which is an attempt to maintain its damaged parts.
\end{abstract}

Keywords: façade, architectural transformation

\begin{abstract}
ABSTRAK
Fasade adalah bagian depan bangunan yang menghadap jalan dan merupakan salah satu elemen arsitektur Kota yang dapat menyuarakan makna dari sebuah bangunan. Selain bisa merepresentasikan si pemilik bangunan, fasade juga merupakan bagian dari tatanan lingkungan kota yang harus berkesinambungan. Peralihan fungsi bangunan seringkali memberikan pengaruh pada perubahan komposisi fasadenya. Oleh karena itu, hal ini sangat menarik untuk diamati terutama pada sepanjang jalan Pakubowono yang memiliki tata bangunan renggang berciri khas aristektur Jengki. Studi ini mencoba mengeksplorasi sejauh mana transformasi arsitektural yang terjadi pada fasade bangunan Gaya Jengki tersebut, dengan menggunakan metode deskriptif. Hasil studi menunjukkan kawasan Pakubowono telah mengalami perubahan dan asimilasi bentuk, walaupun tidak terlalu signifikan merubah tipologi bangunan secara dominan. Perubahan yang terjadi banyak terdapat pada material dan unsur bangunan, yang sifatnya merupakan upaya pemeliharaan bagian yang rusak.
\end{abstract}

Kata kunci: fasade, transformasi arsitektural 


\section{PENDAHULUAN}

Kawasan Kebayoran Baru, Jakarta Selatan merupakan suatu wilayah yang 64 tahun yang lalu telah direncanakan sebagai kota satelit, yang merupakan suatu kota taman yang asri, sejuk dan hijau. Kebayoran Baru merupakan kota taman pertama di Indonesia yangdirancang oleh arsitek Indonesia yaitu H. Moh. Soesilo, dimana pembangunannya dilakukanpada tahun 1948 atas prakarsa Presiden Republik Indonesia pertama yaitu Ir. Soekarnodi atas lahan seluas $730 \mathrm{Ha}$ untuk memenuhi kebutuhanpemukiman warga Jakarta yang kala itu berpenduduk lebih dari satu juta jiwa.Perencanaan Kebayoran Baru merupakan hasil adaptasi dari kota tamanbergaya Eropa seperti layaknya kota taman yang dikembangkan oleh Ir. HermanThomas Karsten di beberapa kota di Bogor, Bandung dan Malang. Selain ituKebayoran Baru menyesuaikan desain kota taman dengan iklim tropis sehinggadapat disebut sebagai Kota Taman Tropis. (Mauboy, 2006).

Pada permulaan masa kemerdekaan sekitar tahun 60-an, di daerah Kebayoran Baru, Jakarta muncullah rumah-rumah bergaya arsitektur jengki. Gaya jengki ini merupakan keinginan dari keinginan dari beberapa pihak untuk 'membebaskan diri' dari segala yang berbau kolonialisme. Termasuk keinginan untuk tidak membuat arsitektur bergaya Belanda. (Sukada, 2004).Gaya Jengki merupakan penolakan terhadap azas - azas arsitektur Kolonial dan Indis, seperti penolakan terhadap simetris serta penolakan bentuk - bentuk detail yang stereotip untuk jendela, pintu dan lain - lainnya. Dan salah satu kawasan permukiman di Kebayoran Baru yang memiliki ciri khas rumah Jengki adalah kawasan Pakubowono.

Sejalan dengan perkembangan dan pertumbuhan kota, perubahan sosial, ekonomi, budaya masyarakat dan kemajuan teknologi arsitektur memberikan dampak dan imbas tersendiri bagi perkembangan rumah tinggal bergaya jengki di kawasan Kebayoran Baru tersebut. Di sepanjang jalan Pakubowono, sejumlah rumah tinggal bergaya jengki kini masih tersisa beberapa unit. Dengan mengamati fenomena rumah tinggal bergaya arsitektur jengki sebagai karya arsitektur khas Indonesia, maka permasalahan yang terjadi adalah semakin sedikitnya rumah bergaya jengki tersebut dan terjadinya transformasi bentuk fasade bangunanjengki menjadi bentuk fasade yang berbeda. Hal ini akan menimbulkan kekuatiran akan menghilang dan lenyap tanpa bekas karya arsitektur "jengki" sebagai ciri khas arsitektur Indonesia.Persoalan menarik yang patut dikemukakan adalah tipologi bangunan bergaya jengki sepanjang jalan Pakubowono.

\section{METODE}

Pendekatan yang digunakan untuk artikel ini hanya sebatas studi literatur dan pengamatan, yang diharapkan dapat memberikan wawasan lain tentang tipologi bangunan yang ada di jalan Pakubowono, Kebayoran Baru Jakarta dan dapat diperoleh masukan yang bermanfaat bagi konservasi bangunan lama di kawasan Kebayoran Baru serta dapat mempertahankan nilai sejarah yang terkandung di dalamnya.

\section{HASIL DAN PEMBAHASAN}

Jengki berdasarkan morfologi (pembentukan kata) berasal dari kata "Yankee", sebuah sebutan untuk orang-orang New England yang tinggal di bagian Utara Amerika Serikat atau seseorang yang lahir dan tinggal di bagian Utara Amerika Serikat, khususnya tentara yang berperang untuk penyatuan dalam Perang Sipil di Amerika (Encarta Dictionary, 2003 dalam Widayat, 2006). Menurut Sukada 
(2004), istilah Yankee mempunyai konotasi negatif. Karakter yang berbeda dari yang berlaku secara umum itu patut diduga memberi inspirasi untuk menamai gaya rumah atau arsitektur yang lahir di Indonesia yang sangat khas, dan tidak sama dibandingkan dengan arsitektur sebelumnya. Istilah jengki juga untuk menyebut model busana tahun 70-an, yakni 'celana jengki' dengan ciri-ciri celana panjang yang ketat dan sangat kecil bagian bawahnya. Roesmanto (2004) mengatakanrumah gaya jengki berbeda dengan arsitektur bergaya kolonial, dan bahkan sangat lain dengan arsitektur tradisional yang ada di Indonesia. Lebih lanjut dijelaskan bahwa sebagai karya arsitektur, rumah gaya jengki dapat dikategorikan sebagai arsitektur modern khas Indonesia.

\section{Transformasi Bentuk Rumah Jengki}

Widayat (2006) mengatakan bahwa rumah jengki lebih didominasi oleh kepentingan fungsi, seperti kemiringan atap agak curam (untuk memudahkan aliran air hujan), bentukan segilima yang melebar ke atas pada dinding sebagai pelindung sinar matahari, teras untuk mengurangi panas ruangan dan lubang angin pada rooster untuk memudahkan sirkulasi udara. Widayat (2006) mengkaji tentang karakteristik bentukan arsitektur jengki di antaranya: (1) atap pelana - sebagian besar dari gaya jengki menggunakan atap pelana yang mengecil pada bagian belakang. Sudut atap kurang lebih $35^{\circ}$. Kedua bidang atap tidak bertemu dan tidak memiliki bubungan; (2) tembok depan miring - pada awal perkembangan, bidang segilima dibentuk oleh dua sisi tegak dari dinding konvensional yang dimiringkan. Hal ini menunjukkan ciri anti geometris dan mirip dengan simbol TNI AU; (3) krawang/rooster - bukaan sebagai adaptasi terhadap iklim tropis dan juga merupakan ekspresi baru. Bentuknya bermacam-macam dari segilima, segitiga, maupun bidang tidak beraturan; (4) teras/beranda, teras berdiri sendiri kalaupun menyatu tidak merusak bidang miring fasade rumah. Teras yang terpisah ini dimungkinkan karena pengaruh sudut atap besar. Terasditutupi oleh atap datar sehingga memberi tekanan yang berbeda dari bangunan utama yang beratap pelana.; (5) bentuk dasar, jika dilihat dari luar memiliki bentukan yang miring, tetapi ketika memasuki ruangnya tetap pada bentukan kubus seperti rumah rakyat pada umumnya; (6) kombinasi bahan, kombinasi pelapisan meliputi bahan lempengan batu belah, pasangan batu serit, kubistis batu paras dan susunan batu telor. Terkadang penyelesaian material masih kasar yaitu semen yang dilemparkan ke dinding tanpa finishing.

Roesmanto (2004) dalam penelitiannya dikatakan bahwa bentukan arsitektur jengki sudah diteorikan, yang mana merupakan evolusi dari rumah kampung dan dekonstruksi terhadap gaya kolonial. Untuk lebih menjelaskan, dapat dilihat pada sketsa berikut (Gambar 1):

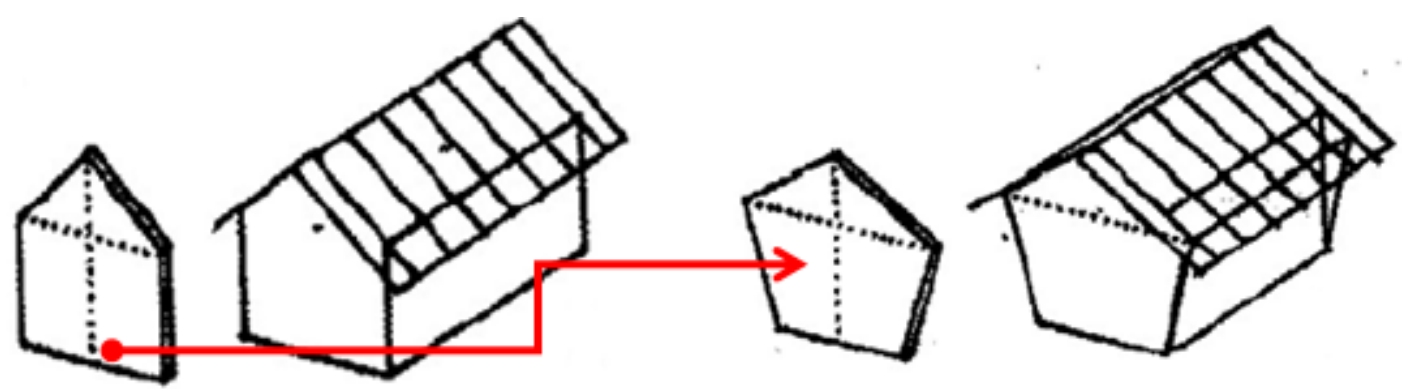

Bentuk Rumah Kampung

Transformasi dinding menjadi bentuk segilima 


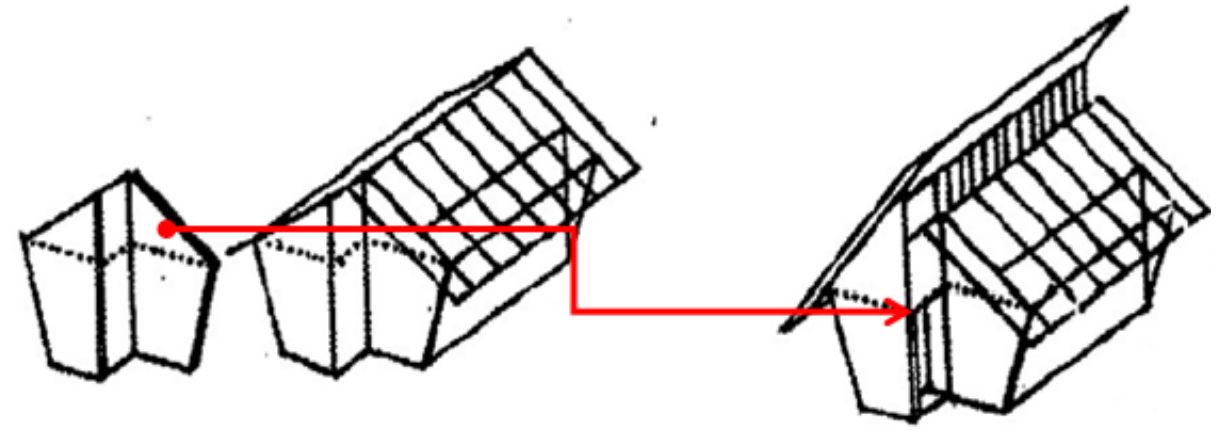

Dinding segi lima dibelah dan ditarik ke depan untuk pintusegi lima dibelah dan ditarik ke depan untuk pintu
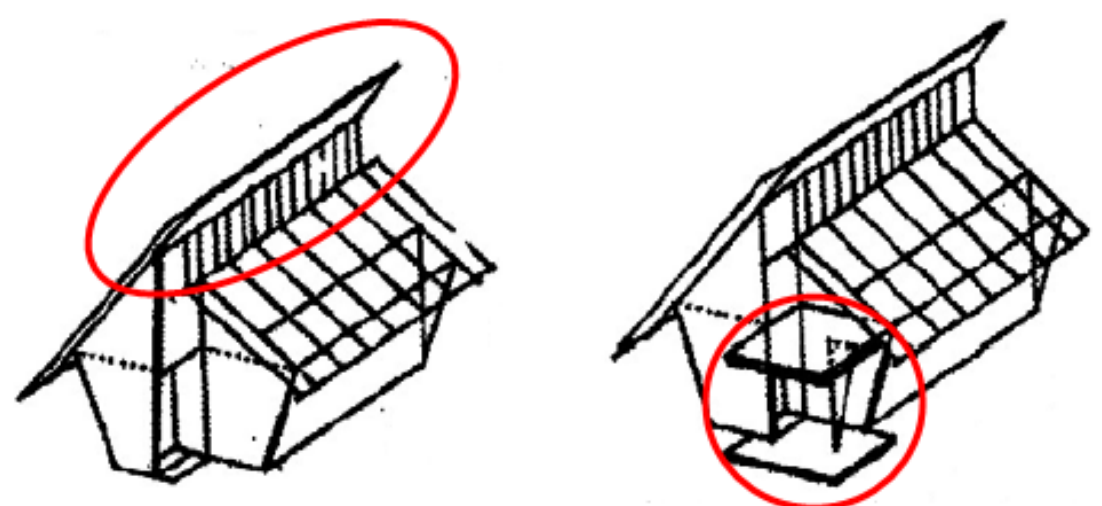

Atap tidak bertemu pada bumbungan, bidang kosong untuk penempatan krepyak yang berfungsi untuk sirkulasi udara dan bidang datar untuk beranda yang disangga pipa besi berbentuk $\mathbf{V}$

Gambar 1Transformasi rumah jengki (Roesmanto, 2004)

\section{Kajian Tipologi dalam Perspektif Arsitektur}

Karen (1994, dalam Mochsen 2005), dalam bahasannya tentang tipe dan tipologi, mengemukakan bahwa tipe menyerupai aspek klarifikasi, yaitu menggabungkan karakteristik yang sama dari kelompok karya arsitektur tersebut secara detail berbeda antara satu dengan yang lainnya. Sedangkan tipologi digunakansebagai alat untuk menganalisis obyek. Dengan tipologi suatu obyekarsitektur dapat dianalisis perubahan-perubahan yang berkaitan denganbangun dasar, sifat dasar, serta proses perkembangan bangunan dasartersebut. Selain itu tipologi juga dapat digunakan untuk menerangkanperubahan-perubahan dari suatu tipe, karena suatu tipe memiliki ciri-ciritertentu yang membedakannya dari tipe yang lain. Jadi dengan kata lain tipologi adalah ilmu yang mempelajari klasifikasi dari tipe, yaitu dengan cara mempelajari karakeristik yang lebih spesifik dari suatu bangunan. Dengan demikian, maka tipologi tidak hanya dibedakan dari bentuknya saja tetapi lebih kearah pada karakter bangunan. Menurut Sulistijowati (1991, dalam Ramadanta, 2010), pengenalan tipologi akan mengarah pada upaya untuk mengkelaskan, mengelompokkan atau mengklasifikasikan berdasarkan pada aspek atau kaidah tertentu antara lain: (1) fungsi (meliputi penggunaan ruang, struktural, simbolis, dan lain-lain); (2) geometrik (meliputi bentuk, prinsip tatanan, dan lain-lain); (3) langgam (meliputi periode, lokasi atau geografi, politik atau kekuasaan, etnik dan budaya, dan lainlain).

\section{Fasade Bangunan}

Prijotomo (1987, dalam Ramadanta, 2010), mengatakan bahwa bagian bangunan dan arsitektur yang paling mudah untuk dilihat adalah bagian wajah bangunan atau yang lebih dikenal 
dengan sebutan fasade bangunan. Bagian fasade bangunan ini juga sering disebut tampak, kulit luar ataupun tampang bangunan, karena fasade bangunan paling sering diberi penilaian oleh para pengamat tanpa memeriksa terlebih dahulu keseluruhan bangunan baik keseluruhan sisi luar bangunan, maupun pada bagian dalam bangunan. Penilaian tersebut tidak hanya dilakukan oleh para arsitek tetapi juga masyarakat awam.Komposisi suatu fasade, dengan mempertimbangkan semua persyaratan fungsionalnya (jendela, pintu, sun shading, bidang atap) pada prinsipnya dilakukan dengan menciptakan kesatuan yang harmonis dengan menggunakan komposisi yang proporsional, unsur vertikal dan horisontal yang terstruktur, material, warna dan elemen-elemen dekoratif. Hal lain yang tidak kalah penting untuk mendapatkan perhatian yang lebih adalah proporsi bukaan-bukaan, tinggi bangunan, prinsip perulangan, keseimbangan komposisi yang baik, serta tema yang tercakup ke dalam variasi (Krier, 1988 dalam Ramadanta, 2010). Menurut Lippsmeier (1980, dalam Ramadanta, 2010) elemen fasade dari sebuah bangunan yang sekaligus merupakan komponen-komponen yang mempengaruhi fasade bangunan adalah atap, dinding, dan lantai.

\section{Jalan Pakubowono VI}

$5)$.

Di bawah ini ditapilkan beberapa foto Jalan Pakubuwono dahulu dan sekarang (Gambar 2 -

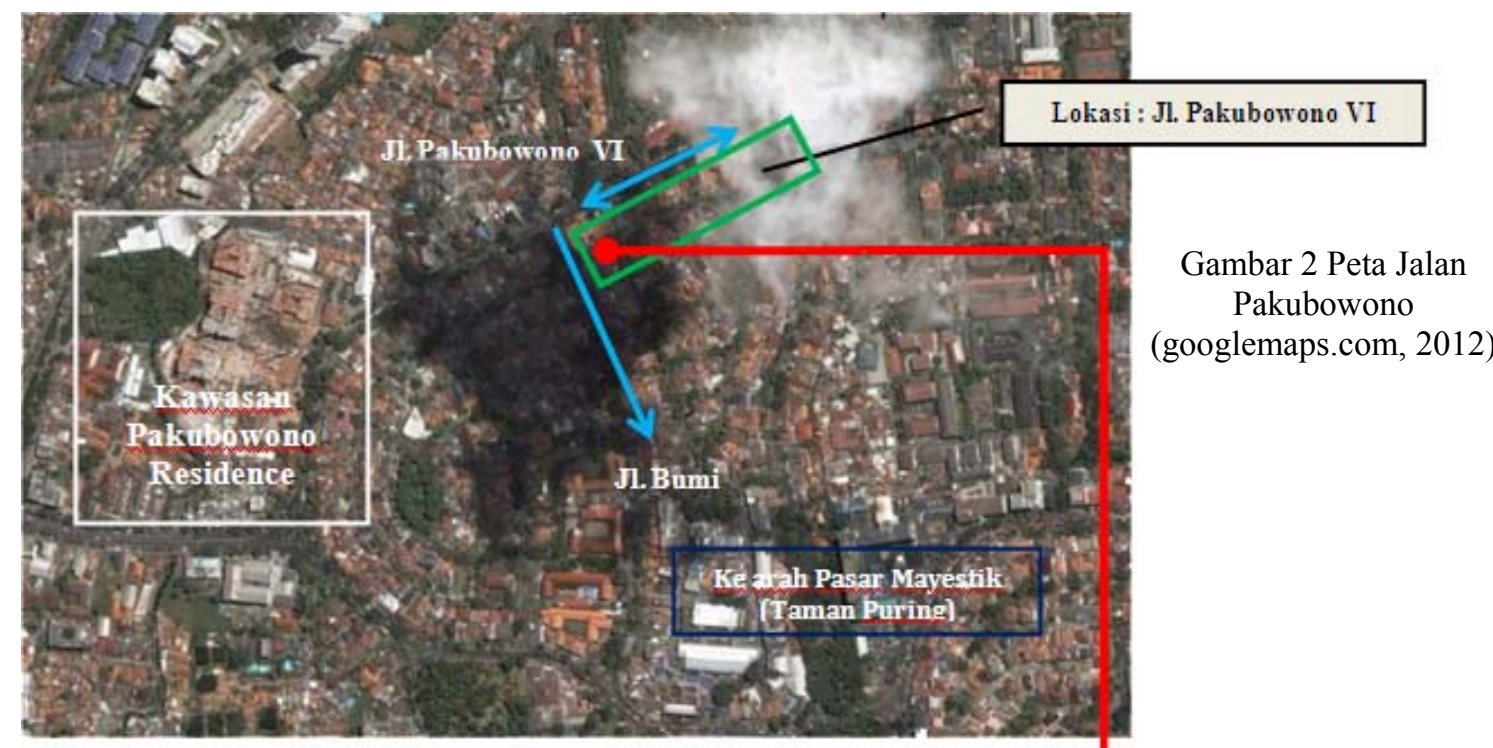

Fasade bangunan di Jl. Pakubowono VI, yang umumnya merupakan tata bangunan terbuka, karena masih didominasi oleh bangunan tempo dulu yang dibangun pada masa tahun 1950an dengan konsep kota taman (Garden City)

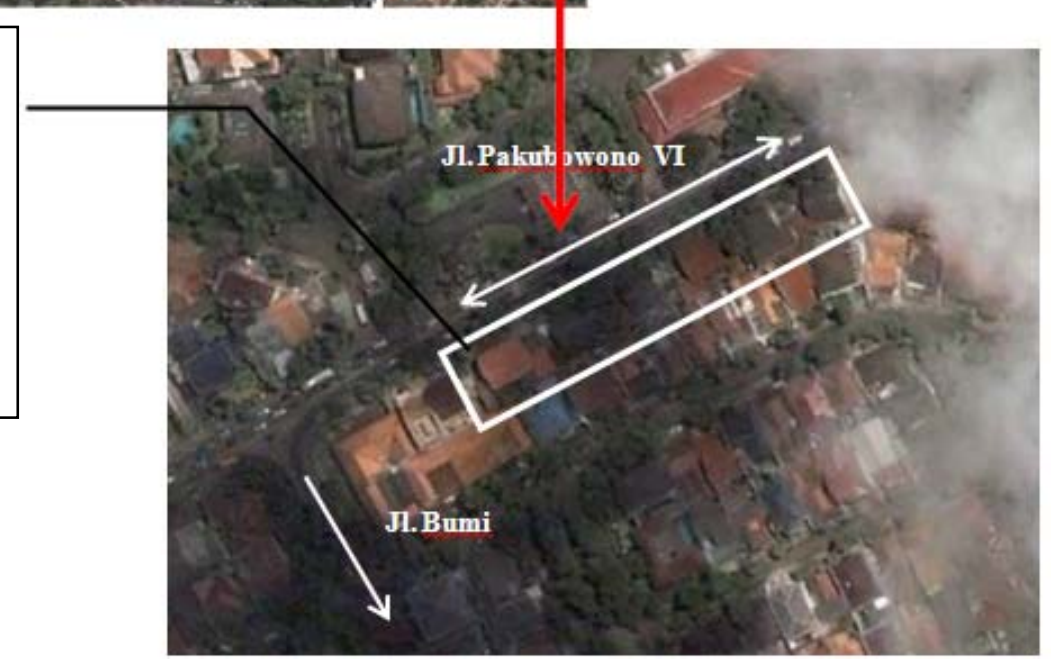

Gambar 3 Peta Jalan Pakubow ono (googlemaps.com, 2012) 


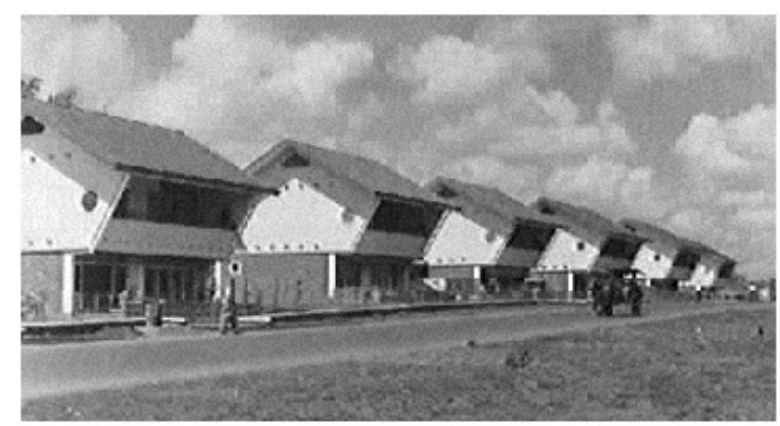

Gambar 4 Kondisi Jl Pakubowono pada tahun 1950 (Harian Kompas, 2004)

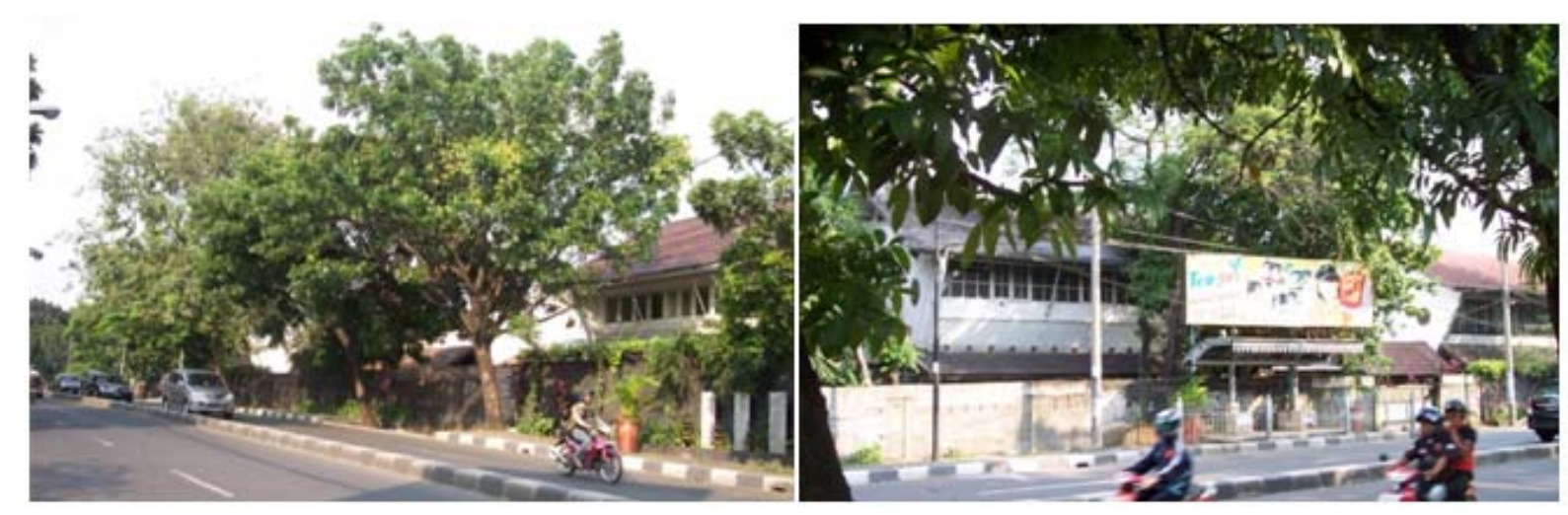

Gambar 5 Kondisi Jl Pakubowono sekarang (dokumentasi pribadi)

\section{Analisis Tipologi Fasade Bangunan}

\begin{tabular}{|c|c|c|}
\hline Rumah yang diamati & Kondisi Sekarang & Hasil Analisis \\
\hline Gambar 6 Rumah pertama (dokumentasi pribadi) & $\begin{array}{l}\text { - Atap berbentuk } \\
\text { pelana, bahan } \\
\text { penutup atap dari } \\
\text { genteng tanah liat } \\
\text { (plentong). } \\
\text { - Dinding tampak } \\
\text { muka dari kaca } \\
\text { dengan kusen } \\
\text { aluminium berwarna } \\
\text { putih. } \\
\text { - Terdapat lubang } \\
\text { angin berbentuk } \\
\text { lingkaran dan } \\
\text { segitiga pada dinding } \\
\text { samping. } \\
\text { - Tampak muka } \\
\text { bangunan } \\
\text { mempergunakan } \\
\text { tiang besi berwarna } \\
\text { putih dengan elemen }\end{array}$ & $\begin{array}{l}\text { - Masih } \\
\text { mempertahankan } \\
\text { bentuk atap pelana } \\
\text { dengan sudut } \\
\text { kemiringan atap } \\
\pm 35^{\circ} \text {.Bahan penutup } \\
\text { atap menggunakan } \\
\text { genteng tanah liat. } \\
\text { - Masih } \\
\text { mempertahankan } \\
\text { dinding depan } \\
\text { miringdan dinding } \\
\text { tampak samping } \\
\text { berbentuk segilima. } \\
\text { - Masih } \\
\text { mempertahankan } \\
\text { rooster sebagai lubang } \\
\text { untuk aliran sirkulasi } \\
\text { udara } \\
\text { - Masih }\end{array}$ \\
\hline
\end{tabular}




\begin{tabular}{|c|c|c|}
\hline & $\begin{array}{l}\text { dekoratif besi seperti } \\
\text { railing balkon. } \\
\text { - Elemen dekoratif } \\
\text { lubang angin } \\
\text { berbentuk lingkaran } \\
\text { kecil terdapat pada } \\
\text { tampak muka dan } \\
\text { tampak samping } \\
\text { - Finishing dinding } \\
\text { plester-aci dan dicat } \\
\text { putih }\end{array}$ & $\begin{array}{l}\text { mempertahankan } \\
\text { bukaan kaca dan } \\
\text { elemen dekoratif besi } \\
\text { pada tampak muka }\end{array}$ \\
\hline Gambar 7 Rumah kedua (dokumentasi pribadi) & $\begin{array}{l}\text { - Atap berbentuk } \\
\text { pelana, bahan } \\
\text { penutup atap dari } \\
\text { genteng beton pres } \\
\text { warna hitam } \\
\text { keabuan. } \\
\text { - Dinding tampak } \\
\text { muka dari kaca } \\
\text { dengan kusen } \\
\text { aluminium berwarna } \\
\text { putih. } \\
\text { - Terdapat lubang } \\
\text { angin berbentuk } \\
\text { lingkaran pada } \\
\text { dinding samping. } \\
\text { - Tampak muka } \\
\text { bangunan } \\
\text { mempergunakan } \\
\text { tiang besi berwarna } \\
\text { hitam tanpa elemen } \\
\text { dekoratif besi seperti } \\
\text { railing balkon. } \\
\text { - Elemen dekoratif } \\
\text { lubang angin } \\
\text { berbentuk lingkaran } \\
\text { kecil hanya terdapat } \\
\text { pada tampak } \\
\text { samping. } \\
\text { - Finishing dinding } \\
\text { plester-aci dan dicat } \\
\text { putih }\end{array}$ & $\begin{array}{l}\text { - Masih } \\
\text { mempertahankan } \\
\text { bentuk atap pelana } \\
\text { dengan sudut } \\
\text { kemiringan atap } \pm 35^{\circ} \text {. } \\
\text { Bahan penutup atap } \\
\text { menggunakan genteng } \\
\text { beton pres. } \\
\text { - Masih } \\
\text { mempertahankan } \\
\text { dinding depan } \\
\text { miringdan dinding } \\
\text { tampak samping } \\
\text { berbentuk segilima. } \\
\text { - Masih } \\
\text { mempertahankan } \\
\text { rooster sebagai lubang } \\
\text { untuk aliran sirkulasi } \\
\text { udara (tampak } \\
\text { samping) } \\
\text { - Masih } \\
\text { mempertahankan } \\
\text { bukaan kaca dan } \\
\text { elemen tiang besi pada } \\
\text { tampak muka. }\end{array}$ \\
\hline 20. & $\begin{array}{l}\text { - Atap berbentuk } \\
\text { pelana, bahan } \\
\text { penutup atap dari } \\
\text { sirap warna hitam. } \\
\text { - Dinding tampak } \\
\text { muka dari kaca } \\
\text { dengan kusen kayu } \\
\text { berwarna putih. } \\
\text { - Terdapat lubang } \\
\text { angin berbentuk } \\
\text { lingkaran dan } \\
\text { segitiga pada dinding } \\
\text { samping. } \\
\text { - Tampak muka } \\
\text { bangunan }\end{array}$ & $\begin{array}{l}\text { - Masih } \\
\text { mempertahankan } \\
\text { bentuk atap pelana } \\
\text { dengan sudut } \\
\text { kemiringan atap } \pm 35^{\circ} \text {. } \\
\text { Bahan penutup atap } \\
\text { menggunakan genteng } \\
\text { sirap. } \\
\text { - Masih } \\
\text { mempertahankan } \\
\text { dinding depan } \\
\text { miringdan dinding } \\
\text { tampak samping } \\
\text { berbentuk segilima. } \\
\text { - Masih }\end{array}$ \\
\hline
\end{tabular}




\begin{tabular}{|c|c|c|}
\hline & $\begin{array}{l}\text { mempergunakan } \\
\text { tiang besi berwarna } \\
\text { putih tanpa elemen } \\
\text { dekoratif besi seperti } \\
\text { railing balkon. } \\
\text { - Elemen dekoratif } \\
\text { lubang angin } \\
\text { berbentuk lingkaran } \\
\text { kecil terdapat pada } \\
\text { tampak muka dan } \\
\text { tampak samping. } \\
\text { - Pintu masuk } \\
\text { menggunakan } \\
\text { atap/overstek dengan } \\
\text { bahan penutup atap } \\
\text { dari genteng beton } \\
\text { - Finishing dinding } \\
\text { plester-aci dan dicat } \\
\text { putih }\end{array}$ & $\begin{array}{l}\text { mempertahankan } \\
\text { rooster sebagai lubang } \\
\text { untuk aliran sirkulasi } \\
\text { udara } \\
\text { - Masih } \\
\text { mempertahankan } \\
\text { bukaan kaca dan } \\
\text { elemen tiang besi pada } \\
\text { tampak muka }\end{array}$ \\
\hline (1) & $\begin{array}{l}\text { - Atap berbentuk } \\
\text { pelana, bahan } \\
\text { penutup atap dari } \\
\text { beton warna orange. } \\
\text { - Dinding tampak } \\
\text { muka dari kaca } \\
\text { dengan kusen } \\
\text { aluminium berwarna } \\
\text { hitam. } \\
\text { - Terdapat lubang } \\
\text { angin berbentuk } \\
\text { lingkaran dan } \\
\text { segitiga pada dinding } \\
\text { samping. } \\
\text { - Tampak muka } \\
\text { bangunan } \\
\text { mempergunakan } \\
\text { elemen dekoratif } \\
\text { besi seperti railing } \\
\text { balkon berwarna } \\
\text { hitam. } \\
\text { - Elemen dekoratif } \\
\text { lubang angin } \\
\text { berbentuk lingkaran } \\
\text { kecil hanya terdapat } \\
\text { pada tampak } \\
\text { samping. } \\
\text { - Pintu masuk } \\
\text { menggunakan } \\
\text { atap/overstekdengan } \\
\text { bahan penutup atap } \\
\text { dari genteng beton. } \\
\text { - Finishing dinding } \\
\text { plester-aci dan dicat } \\
\text { putih }\end{array}$ & $\begin{array}{l}\text { - Masih } \\
\text { mempertahankan } \\
\text { bentuk atap pelana } \\
\text { dengan sudut } \\
\text { kemiringan atap } \pm 35^{\circ} \text {. } \\
\text { Bahan penutup atap } \\
\text { menggunakan genteng } \\
\text { beton. } \\
\text { - Masih } \\
\text { mempertahankan } \\
\text { dinding depan } \\
\text { miringdan dinding } \\
\text { tampak samping } \\
\text { berbentuk segilima. } \\
\text { - Masih } \\
\text { mempertahankan } \\
\text { rooster sebagai lubang } \\
\text { untuk aliran sirkulasi } \\
\text { udara } \\
\text { - Masih } \\
\text { mempertahankan } \\
\text { bukaan kaca dan } \\
\text { elemen dekoratif besi } \\
\text { pada tampak muka }\end{array}$ \\
\hline
\end{tabular}




\section{Fasade Bangunan Bagian dari Ruang Publik}

Jalan merupakan ruang publik, yang menjadi milik Negara dan bersifat terbuka serta dapat diakses 24 jam oleh siapapun, sedangkan bangunan merupakan ruang privat yang dimiliki oleh masing - masing penghuni/pemilikbangunan tersebut. Jalan Pakubowono merupakan salah satu jalan yang bersifat terbuka dengan tata bangunan renggang (open bebouwings). Tata bangunan renggang merupakan warisan arsitektur pasca kemerdekaan yang berkonsep kota taman dan gaya bangunannya bergaya arsitektur Jengki. Bangunan ini merupakan deretan bangunan dengan tata bangunan terbuka (renggang), yang memiliki taman pada setiap kavling sehingga tipologi jalan yang terbentuk adalah jalan terbuka (Gambar 10).

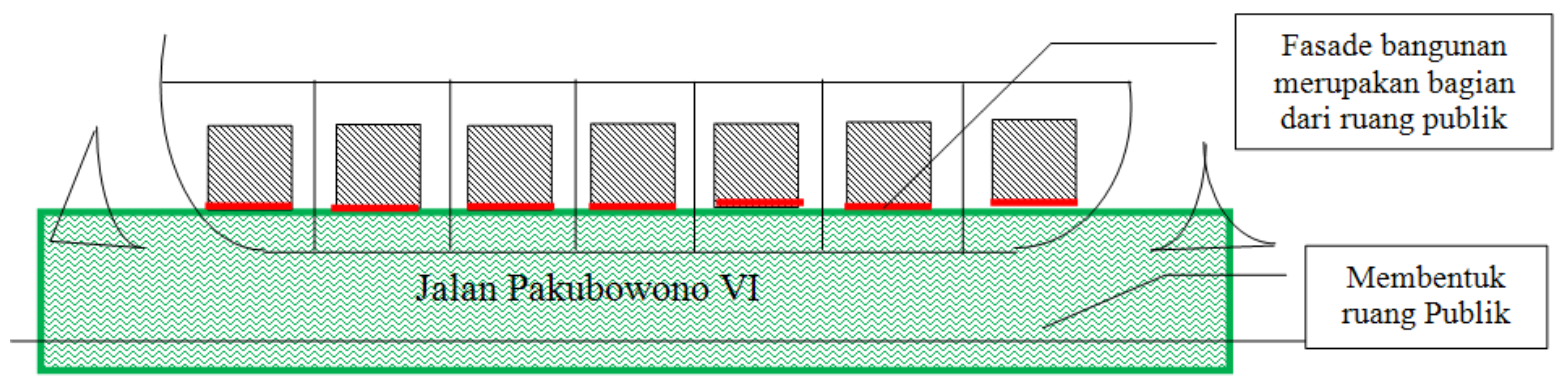

$p$

Gambar 10 Tata bangunan dijalan akubowono (pribadi)

Fasade yang terbentuk pada bangunan juga merupakan bagian dari ruang publik, yang dapat dilihat dan dinikmati oleh semua pengguna area publik tersebut. Tentunya pada kawasan tersebut harus memiliki tipologi bangunan yang menyatu sehingga fasade publik (Gambar 11) yang terbentuk tidak berantakan.

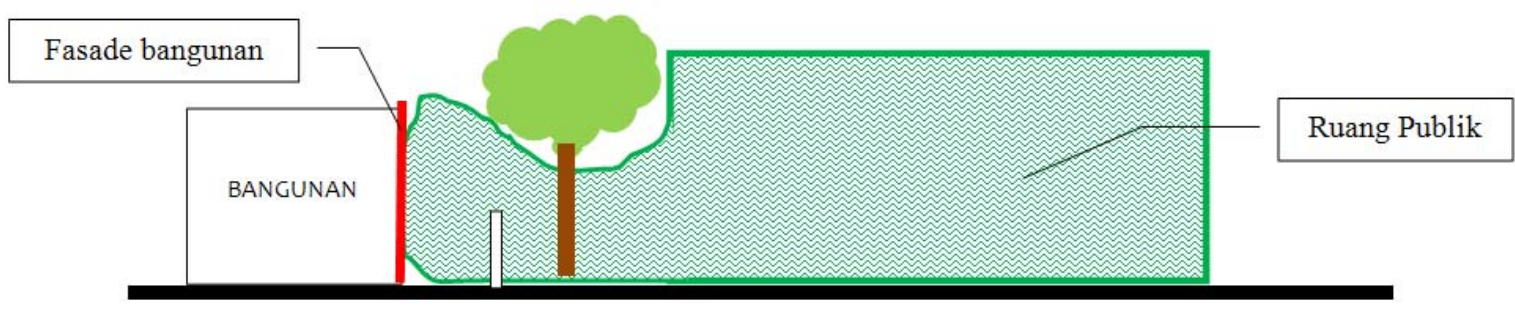

Gambar 11 Potongan dijalan Pakubowono (pribadi)

Kawasan Kebayoran Baru merupakan salah satu kawasan yang memiliki bangunan dengan gaya arsitektur tempo dulu yang dipertahankan sebagai kawasan cagar budaya. Kelanjutan perkembangan kawasan saat ini telah menunjukkan perubahan dan asimilasi bentuk dari tipologi bangunan yang ada terutama di sepanjang jalan Pakubowono. Walaupun perubahan itu tidak secara signifikan merubah tipologi bangunan secara dominan. Perubahan yang banyak terjadi adalah pada beberapa unsur dan material bangunan yang sifatnya sebagai upaya pemeliharaan bagian yang rusak. Perubahan yang dilakukan dapat dilihat seperti pada penggantian material atap dan beberapa bagian pada kusen jendela dan pintu tanpa merubah form atau siluet bangunan secara keseluruhan sehingga secara visual bentuk dan tipologi bangunan pada jalan Pakubowono ini masih dapat dipertahankan, secara unit. 
Sehingga Jalan Pakubowono memiliki identitas dan tipologi bangunan yang menyatu dengan ruang publik, dimana masyarakat atau pengguna jalan (ruang publik) tersebut dapat menikmati suasana kawasan konservasi bangunan lama/tua yang dipertahankan sebagai salah satu warisan budaya, walaupun pada kenyataannya jumlah bangunan yang tersisa hanya beberapa unit saja.

\section{PENUTUP}

Jalan merupakan ruang publik yang bersifat terbuka dan dapat diakses 24 jam oleh siapapun, seperti Jalan Pakubowono yang merupakan salah satu jalan yang bersifat terbuka dengan tata bangunan renggang (open bebouwings), dimana tata bangunan renggang merupakan warisan arsitekturpasca kemerdekaan yang berkonsep kota taman dan gaya bangunannya bergaya arsitektur Jengki.Fasade yang terbentuk pada tampak muka bangunan merupakan bagian dari ruang publik, yang dapat dilihat dan dinikmati oleh semua pengguna area tersebut. Sebagai warisan arsitektur modern khas Indonesia, kawasan di sepanjang jalan Pakubowono dapat dijadikan sebuah kawasan cagar budaya, yang mempunyai makna untuk mengekspresikan gayahidup pola kebudayaan adaptif pada zamannya.Hal ini dapat dilakukanuntuk melestarikan dan mencegahnya dari kepunahan.

Dari hasil pengamatan penulis terhadap tipologi bangunan yang masih tersisa di sepanjang jalan Pakuowono, dapat diambil kesimpulan bahwa: (1) atap masih dipertahankan dari bentukawal yaitu atap pelana, dengan kemiringan atap $\geq 35^{\circ} ;(2)$ mempertahankan bukaan seperti kaca, jendela sepanjang tampak muka di lantai dua; (3) mempertahankan bentuk dinding segilima pada tampak samping sebagai hasil kreativitas dari arsitektur jengki; (3) masih mempertahankan elemen dekoratif tiang besi miring pada tampak muka bangunan.; (6)mempertahankan penggunaan rooster sebagai lubang sirkulasi angin baik pada tampak samping dan juga tampak muka.

\section{DAFTAR PUSTAKA}

Mauboy CW. (2006). Building Initiative on Heritage Conservation in Jakarta.

Mochsen Sir, Mohammad. (2005). Tipologi Geometri: Telaah Beberapa Karya Frank L. Wright dan Frank O. Gehry (Bangunan Rumah Tinggal sebagai Obyek Telaah). Jurnal Rona, 2 (1): 69-83

Ramadanta, Asyra. (2010). Kajian Tipologi dalam Pembentukan Karakter Visual dan Struktur Kawasan. Studi Kasus : Kawasan Ijen, Malang. Jurnal SMARTek, 8 (2): 130-142

Roesmanto, Totok. 25 Juli (2004). Menjengki Diri. Jakarta: Harian Suara Merdeka.

Skripsi tidak dipublikasikan. Program Studi Teknik Arsitektur, Fakultas Teknik, Universitas Budi Luhur, Jakarta.

Sukada, Budi. (2004) . "Langgam Jengki Langgam Khas Indonesia".Disarikan dari Bahan Kuliah Ir. Budi Sukada Jurusan Arsitektur UI.

Widayat, Rahmanu. (2006). Spirit dari Rumah Gaya Jengki ulasan tentang Bentuk, Estetika, Dan Makna. Jurnal Dimensi Interior. 4 (1): 80-89 